\title{
ЗМІНИ ПОКАЗНИКІВ ПЕРОКИДАЦІї ЛІПІДІВ, ГЛУТАТІОНОВОЇ ЛАНКИ ПРОТИОКСИДАНТНОГО ЗАХИСТУ, ІЛ-18, ІЛ-10 ТА МАТРИЛІНУ 3 У ХВОРИХ НА ОСТЕОАРТРОЗ, ПОЄДНАНИЙ З ЦУКРОВИМ ДІАБЕТОМ 2 ТИПУ, ОЖИРІННЯМ, АРТЕРІАЛЬНОЮ ГІПЕРТЕНЗІЕЮ
}

\author{
ВДНЗ України «Буковинський державний медичний університет», м. Чернівці
}

РЕЗЮМЕ. Низка досліджень вказує, що оксидативний стрес (ОС) впливає на патогенез та прогресування остеоартрозу (ОА). Відомо, що ОС $є$ порушенням рівноваги між прооксидантними й антиоксидантними системами в клітинах і тканинах. Інтенсифікація пероксидного окиснення ліпідів (ПОЛ) призводить до вивільнення прозапальних цитокінів, порушення мікроциркуляції, структури колагену і сприяє прогресуванню дегенеративного процесу в суглобових тканинах.

Мета дослідження - визначити зміни показників пероксидації ліпідів та глутатіонової ланки протиоксидантного захисту, ІЛ-18, ІЛ-10 та матриліну 3 у хворих на остеоартроз, поєднаний з цукровим діабетом 2 типу, ожирінням, артеріальною гіпертензією.

Матеріал і методи. Обстежено 116 пацієнтів із цукровим діабетом 2 типу, ожирінням та артеріальною гіпертензією, віком від 16 до 65 років (середній вік склав 40,5 років). При розподілі хворих на групи за віком були прийняті якісні вікові періоди, рекомендовані комітетом експертів Всесвітньої організації охорони здоров'я (ВООЗ) [37]: молодий вік (16-29 років) - 0,79 \%, зрілий вік (30-44 роки) - 10,24 \%, середній вік (45-59 років) - 53,54 \%, похилий вік (60-65 років) - 35,43\%. Основна частина хворих була середнього працездатного віку. Було виділено 4 клінічні групи динамічного спостереження (хворі з ізольованим остеоартрозом та із супутніми захворюваннями).

Пероксидацію ліпідів вивчали за методикою Владимирова Ю. А (1999), стан показників глутатіонової ланки протиоксидантного захисту - титраційним методом за О. В. Травіною в модифікації І. Ф. Мещишена, І. В. Петрової (1983). Дослідження цитокінів у сироватці крові: інтерлейкінів 10 та 18 - виконано з використанням відповідних наборів фірми Bender MedSystems GmbH (Австрія) твердофазовим імуноферментним методом Platinum ELISA, згідно з інструкцією виробника.

Результати. У всіх групах хворих показники малонового альдегіду підвищувалися, але більшою мірою у пацієнтів, у яких остеоартроз перебігав із цукровим діабетом типу 2, ожирінням та артеріальною гіпертензією. Зниження антиоксидантного захисту за даними глутатіону відновленого найвираженішим було також у хворих цієї групи. Показники ІЛ-18 були найвищими при остеоартрозі з ожирінням та артеріальною гіпертензією, а ІЛ-10 - за наявності цукрового діабету. Показники матриліну 3 змінювалися неоднозначно.

Висновки. У хворих на остеоартроз із цукровим діабетом 2 типу, ожирінням та артеріальною гіпертензією значно порушується рівновага між процесами пероксидації ліпідів та глутатіоновою ланкою протиоксидантного захисту, що асоціюється з активацією ІЛ-18 і суттєвою недостатністю ІЛ-10. Показники матриліну 3 знижуються при ізольованому остеоартрозі та за його поєднання з артеріальною гіпертензією, підвищуючись у III та IV групах порівняно з ПзО.

КлючОВІ СЛОВА: остеоартроз; цукровий діабет 2 типу; ожиріння; артеріальна гіпертензія; окисний стрес; система протиоксидантного захисту; цитокіни, матрилін 3.

Вступ. Остеоартроз (ОА) розпочинається з порушень на молекулярному рівні (анормальний метаболізм у тканинах суглобів) з наступними анатомічними та фізіологічними порушеннями, що призводять до розвитку клінічно вираженого перебігу [1]. Прогресуючу втрату суглобового хряща, хрящову кальцифікацію, формування остеофітів, порушення ремоделювання субхондральної кістки та запалення синовіальної оболонки відносять до основних проявів ОА $[2,3]$. Його розвиток характеризується клітинним стресом і деградацією екстрацелюлярного матриксу, що виникає при мікро- i макропошкодженні, які активують ненормальну (патологічну) адаптивну відновлювальну відповідь імунної системи, включаючи прозапальні шляхи [2]. ОА не тільки впливає на якість життя та скорочує функціонально активний період, а й збільшує смертність через прогресування супутніх захворювань, таких як депресія та серцево-судинні події [4]. Частіше суглоб розглядають не як сукупність кісткових суглобових поверхонь, хрящових структур, синовіальної рідини, суглобової капсули і періартикулярного апарату, а як єдиний орган, з властивими йому складовими, а саме запальними, нейротрофічними, імунними, метаболічними і функціональними [5]. На сучасному етапі ОА розглядають як органне захворювання, а з урахуванням ураження різних суглобових груп - як поліорганне [6]. Поєднання ОА із цукровим діабетом типу 2, артеріальною гіпертензією, абдомінальним ожирінням трапляється часто. Вважають, що ці захворювання мають ряд загальних механізмів про- 
Огляди літератури, оригінальні дослідження, погляд на проблему, ювілеї

гресування (хронічне системне генералізоване імунологічне запалення, інсулінорезистентність, дисліпідемія, генетичні зміни регуляції як загальних процесів, так і зрушень на місцевому рівні).

Мета дослідження - вивчення змін показників пероксидації ліпідів та глутатіонової ланки протиоксидантного захисту, ІЛ-18, ІЛ-10 та матриліну 3 у хворих на остеоартроз за умов поєднання з цукровим діабетом 2 типу, ожирінням, артеріальною гіпертензією.

Матеріали та методи. Обстежено 116 пацієнтів із цукровим діабетом 2 типу, ожирінням та артеріальною гіпертензією, віком від 16 до 65 років (середній вік склав 40,5 років). При поділі хворих на групи за віком були прийняті якісні вікові періоди, рекомендовані комітетом експертів Всесвітньої організації охорони здоров'я (ВООЗ): молодий вік (16-29 років) - 0,79 \%, зрілий вік (3065 років) - 35,43 \%. Основна частина хворих була середнього працездатного віку.

3 урахуванням скарг, анамнезу, об'єктивного статусу, даних загальноклінічних та інструментальних методів обстеження були виділені наступні клінічні групи динамічного спостереження: I група - 37 хворих на остеоартроз; II група - 21 хворий на ОА у поєднанні з артеріальною гіпертензією; III група - 41 хворий на ОА із супутньою артеріальною гіпертензією та абдомінальним ожирінням; IV група - 17 хворих на ОА у поєднанні з цукровим діабетом типу 2, артеріальною гіпертензією та абдомінальним ожирінням; V група - 25 практично здорових осіб. Стаціонарний етап лікування відбувався у ревматологічному відділенні ОКУ «Чернівецька обласна клінічна лікарня» упродовж 20152017 рр. При виконанні роботи керувалися загальноприйнятими світовими та вітчизняними нормативно-правовими директивними документами: основними стандартами GCP (GoodClinicalPractice, Належна клінічна практика, 1996) [7], Конвенцією Ради Європи про права людини та біомедицину (від 04.04.1997) [8], основними принципами Гельсинської декларації щодо біометричних досліджень (1974), адаптованої на XXXXI Міжнародній Асамблеї в Гонконзі (1989), в яких людина виступає об'єктом, а також «Етичних принципів медичних наукових досліджень із залученням людських суб'єктів», прийнятих 52 Асамблеєю Всесвітньої медичної асоціації (2000) [9], Наказами МОЗ України № 281 від 01.11.2000 р., № 66 від 13.02.2006 р. та № 690 від 23.09.2009 р. Карта досліджень та формуляр інформованої згоди пацієнта схвалені комісією з питань біомедичної етики ВДНЗ України «Буковинський державний медичний університет» МОЗ України (м. Чернівці).

Діагноз ОА встановлювали на основі скарг, анамнезу, результатів клініко-лабораторних та інструментальних досліджень згідно з діагностичними критеріями наказу МО3 України від 12.10.2006 р. № 676 «Клінічний протокол надання медичної допомоги хворим із остеоартрозом" та American College of Rheumatology (ACR, 1991).

Оцінка антропометричних показників полягала у визначенні індексу маси тіла (IMT), а також співвідношення ОТ/ОС. Відповідно до загальноприйнятих критеріїв при визначенні ОТ>94 см у чоловіків та >80 см у жінок констатовано абдомінальне ожиріння. Згідно з індексом Кетле, діагноз «ожиріння»

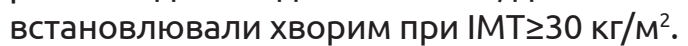

3 метою виявлення та оцінки перебігу супутньої патології серцево-судинної системи, зокрема, артеріальної гіпертензії, хворим проводили інструментальні дослідження-електрокардіографію (виконано за загальноприйнятою методикою), офтальмоскопію, вимірювання артеріального тиску (АТ). Діагноз АГ було верифіковано згідно з наказом Міністерства охорони здоров'я України № 384 від 24.05.2012 р. та рекомендаціями Української асоціації кардіологів, 2012 ; ESC, ESH, 2013.

Діагноз ЦД встановлювали згідно з наказом МО3 України від 21.12.2012 р. № 1118. Верифікацію діагнозу «цукровий діабет 2-го типу» проводили на основі «Уніфікованого клінічного протоколу спеціалізованої медичної допомоги: ЦД 2-го типу» (2012).

3 метою оцінки больового синдрому та загального стану хворого застосовували: альгофункціональний індекс Лекена (Lequesne); індекс WOMAC (Western Ontario and McMaster University) - анкету для самостійної оцінки пацієнтом ступеня вираженості болю (в спокої та при ходьбі - 5 питань), скутості (тривалість та вираженість - 2 питання), функціональної недостатності в повсякденній діяльності (17 питань).

Усім хворим на ОА проведене рентгенологічне обстеження уражених суглобів з визначенням рентгенологічної стадії ОА за J. Н. Kellgren i I. Lawrence.

Вивчення пероксидного окиснення ендогенних ліпідів проводили з тіобарбітуровою кислотою [10]. Вміст відновленого глутатіону (ВГ), глутатіонпероксидази, глутатіонтрансферази в крові визначали за [11].

Дослідження цитокінів у сироватці крові: інтерлейкінів 10 та 18, виконано з використанням відповідних наборів фірми Bender Med Systems $\mathrm{GmbH}$ (Австрія) твердофазовим імуноферментним методом PlatinumELISA, згідно з інструкцією виробника до кожного з наборів зазначених цитокінів у сертифікованій лабораторії імуноферментних досліджень Чернівецької обласної дитячої лікарні № 2 на імуноферментному аналізаторі «StatFax 303» (США). 
Огляди літератури, оригінальні дослідження, погляд на проблему, ювілеї

Статистичну обробку проводили за допомогою прикладних програм MS $\circledast$ Excel TM 2010, Primer of Biostatistics $₫ 6.05$ тa Statistica ${ }^{\text {TM }} 7.0$ (Statsoft $\circledast$ Inc). Комп'ютерний реєстр (база даних) отриманих показників створювали в системі Microsoft Exel. Достовірність даних вираховували з застосуванням двовибіркового (для незалежних вибірок) чи парного (для залежних) t-критерію Student при розподілі, близькому до нормального. Статистично вірогідними вважали відмінності при $p<0,05$.

Результати й обговорення. Аналіз клінічних симптомів при ОА (в тому числі і при АГ із ожирінням та у поєднанні з цукровим діабетом 2 типу) показав, що частіше біль проявлявся під час активних та пасивних рухів, у вечірньо-нічний час або після значного перенавантаження, супроводжувався обмеженням амплітуди рухів у суглобах, їх деформацією за рахунок проліферативних змін. Згідно з опитуванням та обстеженням, при наявності АГ у поєднанні з ОА при ожирінні та ЦД 2 типу больовий синдром у спокої турбував $72,2 \%$ пацієнтів, при русі - 50,0 \% та при пальпації $38,9 \%$. Біль при вставанні з положення сидячи турбував $61,1 \%$ осіб, у 55,5 \% пацієнтів рухи в суглобах були обмеженими. Посилення болю, що виникає при підйомі по сходах, відмітили $66,6 \%$ хворих. На біль при ході по рівній місцевості скаржилися 42,2 \% осіб.

Відомо, що активація пероксидації ліпідів на тлі зниження активності антиоксидантної системи відіграє значиму роль у виникненні імунної запальної відповіді та має відношення до хронічного її перебігу.

Показники вмісту малонового діальдегіду плазми та еритроцитів, відновленого глутатіону (ВГ), активність глутатіонпероксидази (ГП), глутатіон-S-трансферази (ГТ) у сироватці крові представлені в таблиці 1.

Таблиця 1. Активність показників оксидативного стресу та антиоксидантного захисту у сироватці хворих на остеоартроз, що поєднується з АГ, ОА та ЦД типу 2 (M士m)

\begin{tabular}{|c|c|c|c|c|c|}
\hline \multirow[b]{2}{*}{ Показники } & \multirow[b]{2}{*}{ Контроль } & \multicolumn{4}{|c|}{ Групи обстежених хворих } \\
\hline & & $\begin{array}{l}\text { I група } \\
\text { OA, n=37 }\end{array}$ & $\begin{array}{c}\text { II група, } \\
\text { ОА+АГ, n=21 }\end{array}$ & $\begin{array}{c}\text { III група } \\
\text { OA+AГ+AO, } \\
n=41\end{array}$ & $\begin{array}{c}\text { IV група } \\
\text { ОА+АГ+AО+ЦД2, } \\
\text { n=17 }\end{array}$ \\
\hline $\begin{array}{l}\text { МДА плазми, } \\
\text { мкмоль/л }\end{array}$ & $3,36 \pm 0,22$ & $\begin{array}{c}3,85 \pm 0,19 \\
p>0,05\end{array}$ & $\begin{array}{c}4,61 \pm 0,17 \\
p<0,001 \\
p_{1}=0,004\end{array}$ & $\begin{array}{c}4,83 \pm 0,19 \\
\mathrm{p}<0,001 \\
\mathrm{P}_{1}<0,001 \\
\mathrm{P}_{2}>0,05\end{array}$ & $\begin{array}{c}5,09 \pm 0,21 \\
\mathrm{p}<0,001 \\
\mathrm{P}_{1}<0,001 \\
\mathrm{P}_{2}=0,084 \\
\mathrm{P}_{3}>0,05\end{array}$ \\
\hline $\begin{array}{l}\text { МДА еритроцитів, } \\
\text { мкмоль/л }\end{array}$ & $9,43 \pm 0,11$ & $\begin{array}{l}9,51 \pm 0,13 \\
p>0,05\end{array}$ & $\begin{array}{l}9,65 \pm 0,15 \\
p>0,05 \\
p_{1}>0,05\end{array}$ & $\begin{array}{c}10,57 \pm 0,21 \\
\mathrm{p}<0,001 \\
\mathrm{P}_{1}<0,001 \\
\mathrm{P}_{2}<0,001\end{array}$ & $\begin{array}{c}11,61 \pm 0,19 \\
\mathrm{p}<0,001 \\
\mathrm{P}_{1}<0,001 \\
\mathrm{P}_{2}<0,001 \\
\mathrm{P}_{3}<0,001\end{array}$ \\
\hline $\begin{array}{l}\text { Глутатіон } \\
\text { відновлений, ммоль/л }\end{array}$ & $0,74 \pm 0,05$ & $\begin{array}{c}0,61 \pm 0,04 \\
p=0,047\end{array}$ & $\begin{array}{c}0,59 \pm 0,03 \\
p=0,014 \\
p_{1}>0,05\end{array}$ & $\begin{array}{l}0,44 \pm 0,02 \\
\mathrm{p}<0,001 \\
\mathrm{p}_{1}<0,001 \\
\mathrm{P}_{2}<0,001\end{array}$ & $\begin{array}{c}0,39 \pm 0,02 \\
\mathrm{p}<0,001 \\
\mathrm{P}_{1}<0,001 \\
\mathrm{P}_{2}<0,001 \\
\mathrm{P}_{3}>0,05\end{array}$ \\
\hline $\begin{array}{l}\text { Глутатіонпероксидаза, } \\
\text { нмоль ВГ/хв*г } \\
\text { гемоглобіну }\end{array}$ & $215,61 \pm 16,20$ & $\begin{array}{c}225,1 \pm 7,36 \\
p>0,05\end{array}$ & $\begin{array}{c}241,73 \pm 21,74 \\
p>0,05 \\
p_{1}>0,05\end{array}$ & $\begin{array}{c}258,95 \pm 11,21 \\
p=0,031 \\
P_{1}=0,014 \\
P_{2}>0,05\end{array}$ & $\begin{array}{c}271,21 \pm 9,67 \\
p=0,005 \\
p_{1}<0,001 \\
p_{2}>0,05 \\
p_{3}>0,05\end{array}$ \\
\hline $\begin{array}{l}\text { Глутатіон-S- } \\
\text { трансфераза, нмоль } \\
\text { ВГ/хв*г гемоглобіну }\end{array}$ & $80,96 \pm 7,56$ & $\begin{array}{c}125,77 \pm 11,29 \\
p=0,001\end{array}$ & $\begin{array}{c}132,39 \pm 8,51 \\
p<0,001 \\
p_{1}>0,05\end{array}$ & $\begin{array}{c}146,81 \pm 12,59 \\
\mathrm{p}<0,001 \\
\mathrm{p}_{1}>0,05 \\
\mathrm{p}_{2}>0,05\end{array}$ & $\begin{array}{c}154,75 \pm 10,71 \\
\mathrm{P}<0,001 \\
\mathrm{p}_{1}>0,05 \\
\mathrm{P}_{2}>0,05 \\
\mathrm{P}_{3}>0,05\end{array}$ \\
\hline
\end{tabular}

Примітки: 1. МДА - малоновий діальдегід;

2. p - вірогідність різниці показників із групою контролю; $\mathrm{p}_{1}$ - вірогідність різниць показників із I групою; $\mathrm{p}_{2}$ - вірогідність різниць показників із II групою; р $_{3}$ - вірогідність різниць показників із III групою.

Згідно з отриманими результатами, показники МДА плазми та МДА еритроцитів достовірно підвищувалися, порівняно з показниками практично здорових осіб (ПЗО) (особливо МДА еритроци- 
Огляди літератури, оригінальні дослідження, погляд на проблему, ювілеї

тів в III і IV групах), а зниження глутатіону відновленого найбільш вираженим було у хворих IV групи. Показники глутатіонпероксидази та глутатіон-Sтрансферази достовірно підвищувалися і були найбільш вираженими в III та IV групах пацієнтів. Це може бути наслідком компенсаторних механізмів, при яких збільшується споживання глутатіон-Sтрансферази за одночасної надмірної активації про- цесів ліпопероксидації та атерогенної дисліпідемії у хворих на ОА, АГ із ожирінням та ЦД типу 2 (при цьому глутатіонова ланка виснажується швидко), що потребує відповідної корекції у лікуванні.

Визначення вмісту інтерлейкінів 10, 18 та матриліну 3 у сироватці крові хворих на остеоартроз, що поєднується АГ, ОА, та ЦД типу 2, представлено в таблиці 2.

Таблиця 2. Вміст інтерлейкінів 10, 18 та матриліну 3 у сироватці крові хворих на остеоартроз, що поєднується АГ, $\mathrm{OA}$, та ЦД типу $2(\mathrm{M} \pm \mathrm{m})$

\begin{tabular}{|c|c|c|c|c|c|}
\hline \multirow[b]{2}{*}{ Показники } & \multirow[b]{2}{*}{ Контроль } & \multicolumn{4}{|c|}{ Групи обстежених хворих } \\
\hline & & $\begin{array}{l}\text { I група } \\
\text { OA, } n=37\end{array}$ & $\begin{array}{c}\text { II група, } \\
\text { ОА+AГ, } n=21\end{array}$ & $\begin{array}{c}\text { III група } \\
O A+A \Gamma+A O, n=41\end{array}$ & $\begin{array}{c}\text { IV група } \\
\text { ОА+АГ+AO+ЦД2, } \mathrm{n}=17\end{array}$ \\
\hline IL-18, пг/мл & $180,91 \pm 15,45$ & $\begin{array}{c}183,3 \pm 7,21 \\
p>0,05\end{array}$ & $\begin{array}{c}193,3 \pm 5,61 \\
p>0,05 \\
p_{1}>0,05\end{array}$ & $\begin{array}{c}237,01 \pm 4,38 \\
\mathrm{p}<0,001 \\
\mathrm{p}_{1}<0,001 \\
\mathrm{p}_{2}<0,001\end{array}$ & $\begin{array}{c}208,67 \pm 11,62 \\
p<0,05 \\
p_{1}=0,008 \\
p_{2}=0,042 \\
p_{3}>0,05\end{array}$ \\
\hline IL-10, пг/мл & $14,14 \pm 2,12$ & $\begin{array}{c}8,53 \pm 1,29 \\
p=0,027\end{array}$ & $\begin{array}{c}7,54 \pm 1,61 \\
p=0,017 \\
p_{1}>0,05\end{array}$ & $\begin{array}{l}9,85 \pm 2,46 \\
p>0,05 \\
p_{1}>0,05 \\
p_{2}>0,05\end{array}$ & $\begin{array}{c}12,44 \pm 1,07 \\
p>0,05 \\
p_{1}=0,02 \\
p_{2}=0,016 \\
p_{3}>0,05\end{array}$ \\
\hline MATN3, нг/мл & $43,54 \pm 11,27$ & $\begin{array}{c}27,77 \pm 6,25 \\
p>0,05\end{array}$ & $\begin{array}{c}25,3 \pm 1,33 \\
p>0,05 \\
p_{1}>0,05\end{array}$ & $\begin{array}{c}33,25 \pm 7,92 \\
p>0,05 \\
p_{1}>0,05 \\
p_{2}>0,05\end{array}$ & $\begin{array}{c}55,56 \pm 3,69 \\
p>0,05 \\
P_{1}<0,001 \\
P_{2}<0,001 \\
P_{3}=0,013\end{array}$ \\
\hline
\end{tabular}

Примітки: 1. ПАК - протеолітична активність плазми крові.

2. p-вірогідність різниць показників із групою контролю; $\mathrm{p}_{1}$ - вірогідність різниць показників із І групою; $\mathrm{p}_{2}$ - вірогідність різниць показників із II групою; $\mathrm{p}_{3}$ - вірогідність різниць показників із III групою.

Показники ІЛ-18 підвищувалися в усіх групах хворих, але достовірніше - в III (у тому числі і за міжгруповою різницею). Можливо, це пов'язано з вираженістю низькоінтенсивного запалення не тільки у суглобах, а й у жировій тканині. У пацієнтів IV групи показники були достовірно підвищеними тільки у порівнянні із практично здоровими особами.

Оскільки прозапальні та протизапальні цитокіни повинні врівноважувати імунний статус, інтерес викликали значення показника ІЛ-10 (протизапальний інтерлейкін). Вони у пацієнтів I і II груп знижувалися, що свідчить про достатність імунної відповіді на запалення при ОА та ОА із артеріальною гіпертензією. У III групі відмічена тенденція до підвищення цих показників.

Цей факт може вказувати на порушення балансу компенсаторних можливостей процесів імунного запалення у пацієнтів III групи. При вивченні показників ІЛ-10 та ІЛ-18 у пацієнтів IV групи встановлено, що ІЛ-18 знижується відносно таких у III групі, а ІЛ-10 значно підвищується. Це може вказувати на неправильну імунну відповідь на запалення і фор- мування відповідної компенсації, яка викликає напруження у діяльності імунної системи.

Аналіз результатів вивчення показників матриліну 3 в крові засвідчив його достовірне зниження, порівняно з показниками ПЗО, у пацієнтів I та II груп. У пацієнтів III групи він зберігає нижчі показники відносно ПЗО, але вони достовірно підвищуються, порівняно з такими в ІІ групі. В IV групі показники матриліну 3 достовірно підвищені, порівняно з показниками I, II груп та ПЗО та невірогідно підвищені стосовно таких у III групі, що наводить на думку про однотипність процесів у хрящовій тканині суглобів у хворих III та IV груп.

Висновки. У хворих на остеоартроз із цукровим діабетом 2 типу, ожирінням та артеріальною гіпертензією значно порушується рівновага між процесами пероксидації ліпідів та глутатіоновою ланкою протиоксидантного захисту, що асоціюється з активацією ІЛ-18 і суттєвою недостатністю ІЛ-10. Показники матриліну 3 знижуються при ізольованому остеоартрозі та за його поєднання з артеріальною гіпертензією, підвищуючись у III та IV групах порівняно з ПЗО. 
Огляди літератури, оригінальні дослідження, погляд на проблему, ювілеї

\section{ЛІТЕРАТУРА}

1. Головач И. Ю. Остеоартрит: современные фундаментальные и прикладные аспекты патогенеза заболевания / И. Ю. Головач // Боль. Суставы. Позвоночник. - 2014.- № 3(15).- С. 54-58.

2. Головач І. Ю. Хворобомодифікуюча терапія в чинних рекомендаціях: уроки минулого та можливості майбутнього / І. Ю. Головач // Травма. - 2017. №18 (3).- С.11-21.

3. Владимиров Ю. А. Перекисное окисление липидов в биологической мембране / Ю. А. Владимиров, А. И. Арчаков // Тер. арх. - 1999. - № 6. - С. 62-65.

4. Мещишен И. Ф. Окисление и восстановление в организмах крыс при введении этония / И. Ф. Мещишен, И. В. Петрова // Укр. биохим. журн. - 1983. - № 4. C. 571-573.

5. Abbing H. D. Developments in international / H. D. Abbing // European Journal Health Law. - 2009. No. 16 (1). - P. 81-88.

6. Bijlsma J. W. Osteoarthritis: anupdatewithrele vanceforclinicalpractice / J. W. Bijlsma, F. Berenbaum, F. P. Lafeber // Lancet. - 2011. - No. 377. - P. 2115-2126.

\section{REFERENCES}

1. Holovach, I.Yu. (2014). Osteoartrit: sovremennyye fundamentalnyye i prikladnyye aspekty patogeneza zabolevaniya [Osteoarthritis: modern fundamental and applied aspects of the pathogenesis of the disease]. Bol Sustavy. Pozvonochnyk - Pain. Joints. Spine,3 (15), 54-58 [in Russian].

2. Holovach, I.Yu. (2017). Khvorobomodyfikuiucha terapiia v chynnykh rekomendatsiiakh: uroky mynuloho ta mozhlyvosti maibutnioho [Diseases modification therapy in valid recommendations: lessons of the past and future possibilities]. Travma - Injury, 18 (3), 11-21 [in Ukrainian].

3. Vladimirov, Yu.A. (1999). Perekisnoe okisleniye lipidov v biologicheskoy membrane [Peroxide oxidation of lipids in the biological membrane]. Ter. Arkh. - Terr. Arch., 6, 62-65 [in Russian].

4. Meshchishen, I.F. (1983). Okisleniye i vosstanovleniye $v$ organizmakh krys pri vvedenii etoniya [Oxidation and reduction in the body of rats upon administration of ethonium]. Ukr. biokhim. zhurn. - Ukrainian Biochemical Journal, 4, 571-573 [in Russian].

5. Abbing, H.D. (2009). Developments in international. European Journal Health Law, 16 (1), 81-88.
7. Elder B. D. Systematic assessment of growth factor treatment on biochemical and biomechanical properties of engineered articular cartilage constructs / B. D. Elder, K. A. Athanasiou // Osteoarthritis Cartilage. - 2009. No. 17 (1). - P. 114-123.

8. All cause and disease specific mortality in patients with knee or hip osteoarthritis: population based cohort study / E. Nuesch, P. Dieppe, S. Reichenbach // BMJ. 2011. - No. 342. - P. d1165.

9. Otte A. Good clinical practice: historical background and key aspects / A. Otte, H. Maier-Lenz, R. A. Dierckx // Nuclear Medicine Communication. - 2005. - No. 26 (7). P. 563-574.

10. Kraus V. Call for standardized definitions of osteoarthritis and risk stratification for clinical trials and clinical use / V. Kraus // Osteoarthritis Cartilage. - 2015. Vol. 23 (8). - P. 1238-1241.

11. Schoukens $P$. The right to access health care: health care according to European social security law instruments / P. Schoukens // Medical Law. - 2008. No. 27 (3). - P. 501-533.
6. Bijlsma, J.W., Berenbaum, F., \& Lafeber, F.P. (2011). Osteoarthritis: an update with relevance for clinical practice. Lancet, 377, 2115-2126.

7. Elder, B.D., \& Athanasiou, K.A. (2009). Systematic assessment of growth factor treatment on biochemical and biomechanical properties of engineered articular cartilage constructs. Osteoarthritis Cartilage,17 (1), 114-123.

8. Nuesch, E., Dieppe, P., \& Reichenbach, S. (2011). All cause and disease specific mortality in patients with knee or hip osteoarthritis: population based cohort study. BMJ, $342, \mathrm{~d} 1165$.

9. Otte, A., Maier-Lenz, H., \& Dierckx, R.A. (2005). Good clinical practice: historical background and key as pects. Nuclear Medicine Communication, 26,(7), 563-574.

10. Kraus V. (2015). Call for standardized definitions of osteoarthritis and risk stratification for clinical trials and clinical use. Osteoarthritis Cartilage, 23 (8), 12381241.

11. Schoukens, P. (2008). The right to access healthcare: healthcare according to European social security law instruments. Medical Law, 27 (3), 501-533. 


\title{
ИЗМЕНЕНИЯ ПОКАЗАТЕЛЕЙ ПЕРОКСИДАЦИИ ЛИПИДОВ, ГЛУТАТИОНОВОГО ЗВЕНА АНТИОКСИДАНТНОЙ ЗАЩИТЫ, ИЛ-18, ИЛ-10 И МАТРИЛИНА 3 У БОЛЬНЫХ ОСТЕОАРТРОЗОМ ПРИ СОЧЕТАНИИ С САХАРНЫМ ДИАБЕТОМ 2 ТИПА, ОЖИРЕНИЕМ И АРТЕРИАЛЬНОЙ ГИПЕРТЕНЗИЕЙ
}

ФЮ. И. Сердулец

\author{
ВГУз Украины «Буковинский государственный медицинский университет», г. Черновцы
}

РЕЗЮМЕ. Ряд исследований указывает на причастность оксидативного стресса (ОС) к патогенезу и прогрессированию остеоартроза (ОА). Известно, что ОС является нарушением равновесия между прооксидантными и антиоксидантными системами в клетках и тканях. Интенсификация пероксидного окисления липидов (ПоЛ) приводит к высвобождению провоспалительных цитокинов, нарушению микроциркуляции, структуры коллагена и способствует прогрессированию дегенеративного процесса в суставных тканях.

Цель исследования - определить изменения показателей пероксидации липидов и глутатионового звена антиоксидантной защиты, ИЛ-18, ИЛ-10 и матрилина 3 у больных остеоартрозом в сочетании с сахарным диабетом 2 типа, ожирением, артериальной гипертензией.

Материал и методы. Обследовано 116 пациентов с сахарным диабетом 2 типа, ожирением и артериальной гипертензией, в возрасте от 16 до 65 лет (средний возраст 40,5 лет). При распределении больных на группы согласно возрасту принимались качественные возрастные периоды, рекомендованные комитетом экспертов Всемирной организации здравоохранения: молодой возраст (16-29 лет) - 0,79 \%, зрелый возраст (30-44 года) $10,24 \%$, средний возраст (45-59 лет) - 53,54 \%, пожилой возраст (60-65 лет) - 35,43 \%. Основная часть больных соответствовала среднему трудоспособному возрасту. Было выделено 4 клинические группы динамического наблюдения (с изолированным остеоартрозом и сопутствующими заболеваниями).

Пероксидацию липидов изучали по методике Владимирова Ю. А. (1999), состояние показателей глутатионового звена антиоксидантной защиты - по методу О. В. Травиной в модификации И. Ф. Мещишена, И. В. Петровой (1983). Цитокины (ИЛ-18, ИЛ-10) в сыворотке крови исследовали с использованием наборов фирмы Bender MedSystems $\mathrm{GmbH}$ (Австрия) твердофазным иммунноферментным методом согласно инструкции производителя.

Результаты и обсуждение. Во всех группах больных показатели малонового диальдегида повышались, но в большей мере у пациентов, у которых остеоартроз протекал с сахарным диабетом 2 типа, ожирением и артериальной гипертензией. Снижение активности антиоксидантной защиты, согласно данным глутатиона восстановленного, было наиболее выраженным также в этой группе. Показатели ИЛ-18 были наивысшими при остеоартрозе с ожирением и артериальной гипертензией, а ИЛ-10 - при наличии сахарного диабета. Показатели матрилина 3 изменялись неоднозначно.

Выводы. У больных остеоартрозом и сахарным диабетом 2 типа, ожирением и артериальной гипертензией значительно нарушается равновесие между процессами пероксидаии липидов и глутатионовым звеном антиоксидантной защиты, что ассоциируется с активацией ИЛ-18 и существенной недостаточностью ИЛ-10. Показатели матрилина 3 снижаются при изолированном остеоартрозе и при сопутствующей артериальной гипертензии, повышаясь в III и IV группах, в сравнении с ПЗЛ.

КЛЮЧЕВЫЕ СЛОВА: остеоартроз; сахарный диабет 2 типа; ожирение; артериальная гипертензия; окислительный стресс; система антиоксидантной защиты; цитокины; матрилин 3.

\section{CHANGES IN THE INDICATORS OF LIPID PEROXIDATION, GLUTATHIONE LEVEL OF ANTIOXIDANT DEFENSE, IL-18, IL-10, AND MATRILIN 3 IN PATIENTS WITH OSTEOARTHRITIS IN COMBINATION WITH TYPE 2 DIABETES, OBESITY, ARTERIAL HYPERTENSION}

\section{Bukovyna State Medical University, Chernivtsi}

SUMMARY. A number of studies indicate that oxidative stress (OS) is involved in pathogenesis and progression of osteoarthritis (OA). It is known that the OS is a disturbance of the balance between prooxidant and antioxidant systems in cells and tissues. Intensification of lipid peroxidation (LP) leads to the release of proinflammatory cytokines, disturbance of microcirculation, collagen structure and contributes to the progression of the degenerative process in the articular tissues.

The aim of the study - to determine changes in lipid peroxidation and glutathione levels of antioxidant defense,IL-18, IL-10 and matrilin 3 in patients with osteoarthritis in combination with type 2 diabetes, obesity, and arterial hypertension.

Material and Methods. 116 patients with type 2 diabetes, obesity and arterial hypertension aged 16 to 65 years (mean age 40.5 years) were examined. In the distribution of patients in groups by age, qualitative age periods were adopted, recommended by the committee of experts from the World Health Organization (WHO) [37]: young age (16-29 years) $-0.79 \%$,mature age (30-44 years) $-10.24 \%$, middle age ( $45-59$ years) $-53.54 \%$, old age (60-65 years) - $35.43 \%$. 
Огляди літератури, оригінальні дослідження, погляд на проблему, ювілеї

Most of the patients were middle-aged (economically active). Four clinical groups of dynamic observation (with isolated osteoarthritis and concomitant diseases) were identified.

The lipid peroxidation was studied according to the method of Vladimirov Yu. A. (1999), state of indicators of glutathione level of antioxidant defense according to the titration method of $\mathrm{O}$. V. Travina in the modification of I. F. Meshchishen, I. V. Petrova (1983). The analysis of cytokines in blood serum: interleukin 10 and 18, was performed using the appropriate sets of BenderMedSystemsGmbH (Austria) solid-phase enzyme-immunoassay method PlatinumELISA, according to the manufacturer's instructions.

Results and Discussion. In all groups of patients, indicators of malonic aldehyde increased, but in a greater degree in patients where osteoarthritis ran with type 2 diabetes, obesity and hypertension. Reduction of antioxidant defense according to data of glutathione recovered was also the most expressed in patients of this group. Indicators of IL-18 were the highest in osteoarthrosis with obesity and arterial hypertension, and IL-10 - in the presence of diabetes. Indicators of matriline 3 vary ambiguously.

Conclusions. In patients with type 2 diabetes, obesity and arterial hypertension, the balance between lipid peroxidation processes and the glutathione level of antioxidant defense is significantly disturbed, which is associated with activation of IL-18 and significant IL-10 deficiency. Matrilin 3 indicators reduce in isolated osteoarthritis and its combination with arterial hypertension, rising in the III and IV groups compared to the practically healthy individuals (PHI).

KEY WORDS: osteoarthritis; type 2 diabetes; obesity; arterial hypertension; oxidative stress; antioxidant defense system; cytokines; matrilin 3.

Отримано 18.08.2018 